\title{
Gesundheitspflege auf Seeschiffen
}

mit besonderer Berücksichtigung

der

Handelsflotte.

\author{
Von \\ Dr. J. J. Reincke, \\ Physikus in Hamburg.
}

Alle Rechte vorbehalten.

HAMBURG.

L. Friederichsen \& Co.

Land- und Seekartenhandlung.

Admiralität-Strasse $3 / 4$.

1882. 
